\title{
SUPRACONDYLAR OSTEOCHONDROMA IN A BLACK SOUTH AFRICAN POPULATION
}

\author{
1,2David A. Ofusori ${ }^{*},{ }^{1,2}$ Omobola A. Komolafe, ${ }^{1}$ Sunday A Ajayi, ${ }^{2}$ Adeleke A. Abiodun \\ 1. Discipline of Clinical Anatomy, School of Laboratory Medicine and Medical Sciences, \\ University of KwaZulu-Natal, Durban, South Africa. \\ 2. Department of Anatomy and Cell Biology, Faculty of Basic Medical Sciences, Obafemi \\ Awolowo University, Ile-Ife, Osun State, Nigeria
}

Correspondence to David Ofusori Department of Anatomy and Cell Biology, Faculty of Basic Medical Sciences, Obafemi Awolowo University, Ile-Ife, Osun State, Nigeria. e-mail: davidofus234@yahoo.com. Tel: +234-803-445-5715

\begin{abstract}
Osteochondroma is a condition characterized by a benign outgrowth of bone on the surface of another bone. The present study reports the presence of osteochondroma in the supracondylar region of the right femur of a Black South African during a routine osteological study. The diameter of the exostosis measured $15.7 \mathrm{~mm}$ at the tip and $26.3 \mathrm{~mm}$ at the base. The exostosis is about $30.8 \mathrm{~mm}$ from the base of the epicondyle. It is $24.8 \mathrm{~mm}$ in length. Gross examination suggests a feature of osteochondroma.

Keywords: Femur, Osteochondroma, South Africa, tumor
\end{abstract}

\section{INTRODUCTION}

Osteochondroma also known as cartilaginous exostosis, is a condition characterized by an outgrowth of bone on the surface of another bone. Osteochondroma is not only limited to human beings (Unni, 2001), but also found in animals (Franch et al., 2005; Matthews et al., 2012; Pool et al., 1972). When present, osteochondroma may occur singly or in multiple known as osteochondromatosis. It is usually located in places such as hips, elbow, ribs, knees, digits but rarely on the skull. Its manifestation may not be immediate and will always show up later in life. Even though it is usually asymptomatic in some patients, that is not the case for others as the symptoms may range from pain due to compression of adjacent structures to growth retardation. This symptom is also dependent on the location of the exostosis (de Brot et al., 2013). Osteochondromas account for $33.3 \%$ of benign bone tumors in the world (Herget et al 2013; Rao et al., 1996). The incidence rate of Osteochondroma in Asia, Europe, America and Africa were $18.5 \%, 17.2 \%, 9.9 \%$ and $15.2 \%$ respectively (Tong et al., 2017). This present study is an incidental finding of Supracondylar Osteochondroma in a Black South African Population.

\section{MATERIALS AND METHODS}

This study is an incidental finding during a routine osteological study in the Discipline of Clinical Anatomy, University of KwaZulu-Natal, South Africa. Out of 400 femoral bones that were studied, only one presented with osteochondroma. A digital vernier caliper was used to measure the cartilaginous exostosis while a meter rule was used to measure the length of the femur. 


\section{RESULTS}

During a routine osteological study at the Discipline of Clinical Anatomy, School of Medical laboratory Medicine, University of KwaZuluNatal, Durban, South Africa, we observed a right femur with Supracondylar Cartilaginous exostosis (Fig 1). The length of the entire femur was $45 \mathrm{~cm}$. The head circumference was 36.2 $\mathrm{mm}$ while its neck measured $20.8 \mathrm{~mm}$. The upper, middle and lower diameter of the shaft is $23.7 \mathrm{~mm}, 21.8 \mathrm{~mm}$ and $28.4 \mathrm{~mm}$ respectively. The intertrochanteric crest measured $36.5 \mathrm{~mm}$ in length. The lateral and medial articular surfaces measured up to 63.2 $\mathrm{mm}$ and $58.5 \mathrm{~mm}$ respectively. The exostosis measured $15.7 \mathrm{~mm}$ at the tip and $26.3 \mathrm{~mm}$ at the base. The exostosis is about $30.8 \mathrm{~mm}$ from the base of the epicondyle. The intercondylar notch is $16.9 \mathrm{~mm}$ at its widest diameter. It measured $63.2 \mathrm{~mm}$ from the tip to the medial border and $38.4 \mathrm{~mm}$ from the base to the medial border. The distance of the exostosis from the greater trochanter and lesser trochanter are $36 \mathrm{~cm}$ and $31 \mathrm{~cm}$ respectively.
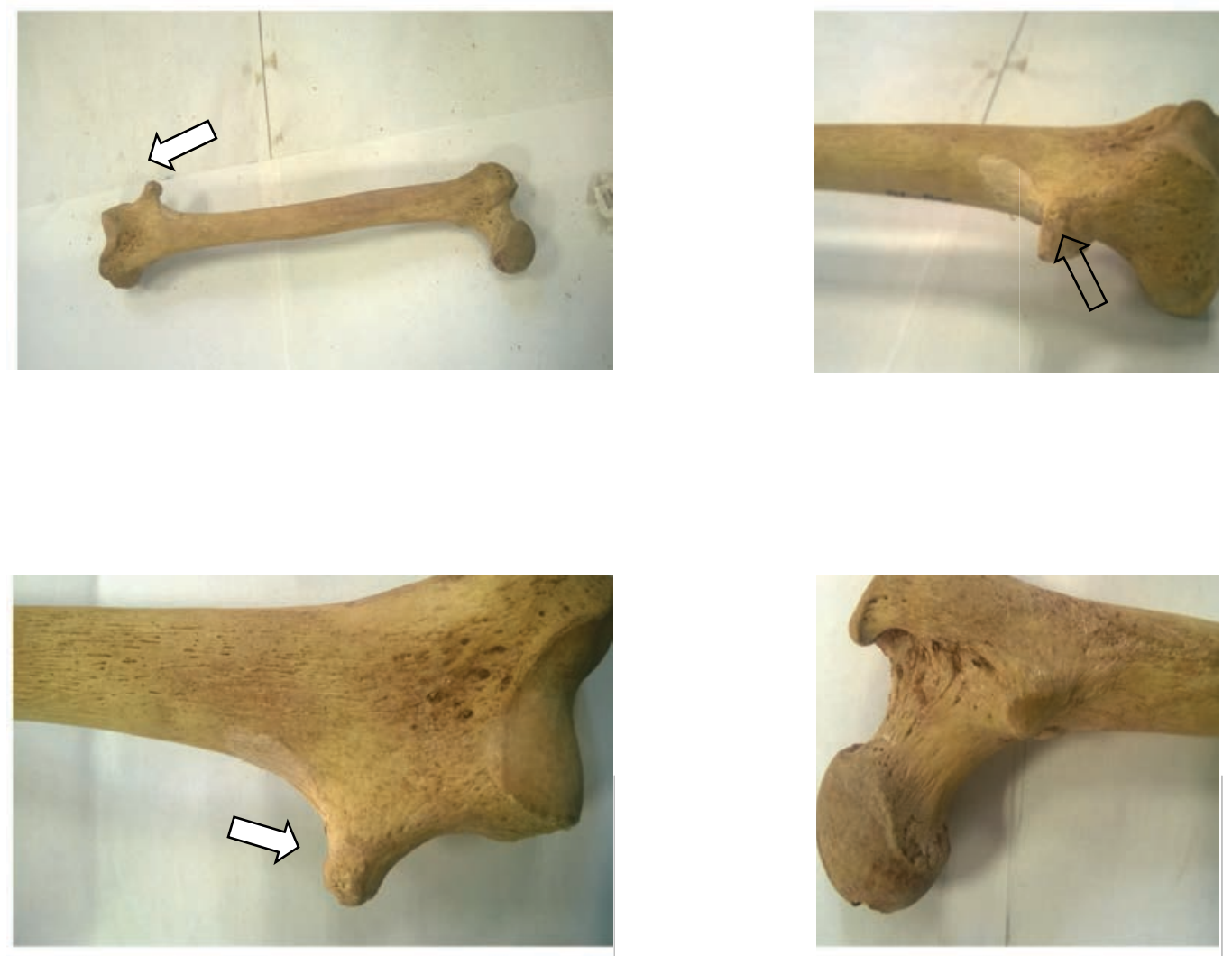

Figure 1: Showing the (a) the anterior view of the right femur (b) inferolateral view of the femur (c) inferiolateral (closer) view of the femur (d) proximal view of the femur, Arrow pointing to cartilaginous exostosis

\section{DISCUSSION}

Gross examination of right femoral bone from this study shows the presence of osteochondroma in a South African population. Even though osteochondroma is rarely reported in humans, documentations have been noted in animals (Franch et al., 2005; le Roux et al., 2014). Multiple osteochondroma is an autosomal dominant disorder present in 
1:50,000 births (Sonne-Holm et al., 2014). It may not be noticeable in young individual but begin to manifest at about age 12 (EL-Sobky et al., 2018). The first noticeable feature is a palpable lump which is mostly bilateral. This condition has no clinical significance (Pollard and Wisner, 2013) except that in some cases, it may hinder growth and cause limb asymmetry (EL-Sobky et al., 2018). Kai Tong et al., 2017 characterized osteochondroma by an epidemiological analysis of the clinical data from one medical institution in South China and noted that osteochondroma have a male predominance in Chinese population and that it occurred mostly at 0-20 years of age. Pierz et al., (2002) and Ahmed et al., (2003) also confirmed that osteochondroma is more frequent in males than females. In adults, it may transform into chondrosarcomas (SonneHolm et al., 2014) or osteosarcoma (de Brot et al., 2013). This has been previously reported in humans and animals (Green et al., 1999; Saglik et al., 2006). Chondrosarcoma is easily suspected when the tumor begins to increase in size after the termination of bone growth thus causing pain as a result of compression of adjacent structures (Peterson, 1998). Biopsy is needed to successfully diagnose chondrosarcomas.

In conclusion, this study has shown that osteochondroma can occur in Black South African population and will provide medical professionals useful information on osteochondroma in South Africa

\section{REFERENCES}

1. Ahmed AR, Unni K, Collins MS. 2003. Secondary chondrosarcoma in osteochondroma: report of 107 patients. Clin Orthop Rel Res; 411:193-206.

2. de Brot S, Grau-Roma L, Vidal E, Segales J. 2013. Occurrence of osteochondromatosis (multiple cartilaginous exostoses) in a domestic pig (Sus scrofa domesticus). Zurich Open Repository and Archive, University of Zurich, ZORA, Pg 1-9.

3. EL-Sobky TA, Samir S, Atiyya AN, Mahmoud S, Aly AS, Soliman R. 2018. "Current paediatric orthopaedic practice in hereditary multiple osteochondromas of the forearm: a systematic review". SICOT-J. doi:10.1051/sicotj/2018002.

4. Franch J, Font J, Ramis A. 2005. Multiple cartilaginous exostosis in a Golden 20 Retriever crossbred puppy. Clinical, radiographic and backscattered scanning 21 microscopy findings. Vet Comp Orthop Traumatol 18:189-193.

5. Green EM, Adams WM, Steinberg H. 1999. Malignant transformation of solitary spinal osteochondroma in two mature dogs. Vet Radiol Ultrasound 40:634-637.

6. Herget GW, Kontny U, Saueressig U. 2013. Osteochondroma and multiple osteochondromas: recommendations on the diagnostics and follow-up with special consideration to the occurrence of secondary chondrosarcoma, Radiologe 53(12): 1125-1136.

7. le Roux C, Kirberger R, Bogner G. 2014. Osteochondroma and multiple cartilagenous exostosis involving the distal radius and ulna on adjacent cortices: an unusual manifestation of a common condition Veterinary Record Case Reports 2: e000049. doi: 10.1136/vetreccr-2014-000049.

8. Matthews KA, Strait K, Connor-Stroud F, Courtney CL. 2012. Osteochondromatosis in a Rhesus macaque (Macaca mulatta). Comp Med 62:149-152.

9. Peterson HA. 1989. Multiple hereditary osteochondromata. Section Ped Orthoped; 239:222-30.

10. Pierz KA, Kusumo K, Dormans JP. 2002. Hereditary multiple exostose: one center's experience and review of etiology. Clin Orthop Rel Res; 401:49-59.

11. Pollard RE, Wisner ER. 2013. Orthopedic diseases of young and growing dogs and cats. In Textbook of Veterinary Diagnostic Radiology 6th edn.Ed D.E. Thrall. Elsevier Saunders. pp 278. 
12. Pool RR, Carrig CB. 1972. Multiple Cartilaginous Exostoses in a Cat. Veterinary Pathology 9:350359.

13. Rao VS, Pai MR, Rao RC, Adhikary MM. 1996. Incidence of primary bone tumours and tumour like lesions In and around Dakshina Kannada district of Karnataka, J. Indian Med.Assoc. 94(3): 103-104,121.

14. Saglik Y, Altay M, Unal VS. 2006. Manifestations and management of osteochondromas: a retrospective analysis of 382 patients. Acta Orthop Belg 72:748-755.

15. Sonne-Holm E, Wong C, Sonne-Holm S. 2014. Multiple cartilaginous exostoses and development of chondrosarcomas - a systematic review. Dan Med J; 61(9): A4895.

16. Tong K, Liu H, Wang X, Zhong Z, Cao S, Zhong C, Yang Y, Wang G. 2017. Osteochondroma: Review of 431 patients from one medical institution in South China Journal of Bone Oncology 8: 23-29.

17. Unni KK. 2001. Cartilaginous lesions of bone. J Orthop Sci 6:457-472. 